\title{
The Influence of Brand Image and Word of Mouth on Interests to Buy of Consumers of Yamaha N-MAX Motorcycle in Lhokseumawe City
}

\author{
T. Edyansyah ${ }^{1}$ \\ \{tedyansyah@unimal.ac.id\} \\ ${ }^{1}$ Faculty of Economyc and Business, Universitas Malikussaleh, Aceh Utara, Indonesia
}

\begin{abstract}
The purpose of this study was to determine the effect of brand image and word of mouth on consumer buying interest of Yamaha N-MAX motorbikes in Lhokseumawe City. The population in this study were consumers who bought a Yamaha N-MAX motorcycle in Lhokseumawe City. Data collection techniques used are questionnaires and literature studies. The questionnaires distributed to 63 consumers who purchased Yamaha N-MAX motorcycle products in Lhokseumawe City. The value of the correlation coefficient $(\mathrm{R})$ is obtained at 0.525 and the value of adjusted $\mathrm{R}_{2}$ is 0.252 or $25.2 \%$ and the remaining $74.8 \%$ is influenced by other factors outside the research model. Based on the partial test results $\left(t_{\text {test }}\right)$, the variable brand image $\left(\mathrm{X}_{1}\right)$ obtained $t_{\text {count }} 2.074>t$ table 2.001 , where that the brand image $\left(\mathrm{X}_{1}\right)$ has a significant effect on consumer buying interest of Yamaha N-MAX motorcycles in Lhokseumawe City, with a significance level 0,000. For simultaneous testing, obtained the value of Fcount 11.427> Ftable 3.15, where simultaneously or simultaneously independent variables consisting of brand image $\left(\mathrm{X}_{1}\right)$ and word of mouth $\left(\mathrm{X}_{2}\right)$ significantly influence the consumer buying interest variable $(\mathrm{Y})$ with significant level of 0.000 .
\end{abstract}

Keywords: Brand Image, Word of Mouth, Buy Interest

\section{Introduction}

Motorbikes are the most favorite mode of transportation used by people today. The choice of motorbikes as the most favorite means of transportation is due to the superiority of the motorbike itself in terms of maintenance costs, fuel costs, the effectiveness of travel time, comfort and ability to break through the traffic jams that occur on the highway. The poor public transportation services also influence the high interest of the people to vote motorbikes as their main means of transportation. The community was made easier to buy motorbikes using the installment or credit system with a mild down payment.

The company must be able to create an attractive brand and describe the benefits of the product in accordance with the wishes of consumers so that consumers have a positive perception of the brand. A good brand image is an asset for a company, because of its brand image it has an impact on each consumer's perception, where the community has a positive impression on the company. Brand image will be a top priority as a reference for consumers before making a purchase. 
Brand image needed so that consumers always remember a brand and continue to stick to the minds of consumers forever. If consumers are looking for a product and want to consume the product, the brand name of the product that they have remembered in their memory will be implied. Brand image, in the end, it will create value that will be very useful for consumers and producers in the long run.

The stage of the respondents' tendency to act before the buying decision is actually implemented is called buying interest. Buying interest will create a motivation that continues to be recorded in the minds of individuals and will arise a very strong desire so that when an individual wants to meet his needs will make a product purchase based on what is in his mind. The interest in buying consumers to buy can arise due to the stimulus (stimulus) offered by the company. Each stimulus is designed to produce actions to buy from consumers.

Yamaha motorbike technology excellence is recognized throughout the world and has been proven on various occasions, both on the road and on the track. Yamaha also developed a technology that was able to answer customer needs, namely "stubborn" and fuel-efficient engines, making it the pioneer of economical two-wheeled vehicles. No wonder the resale price of Yamaha motorcycles remains high.

Phenomena that occurred in the city of Lhokseumawe society today is the switch from the regular motor into the motor Matic one of them is Yamaha N-Max. Motor Matic Yamaha $\mathrm{N}-\mathrm{Max}$ as a new variation in the world of motorbikes, the presence of an automatic transmission motorbike where drivers no longer need to move gears on the motorized vehicles they only need to pull the gas and pull the brake lever so it is very easy and efficient.

Based on the background of the above research, problems can be formulated, namely (1).What is the influence of brand image on consumer buying an interest in Yamaha N-MAX motorcycles in Lhokseumawe City? (2). What is the influence of word of mouth on consumer buying interest in Yamaha N-MAX motorcycles in Lhokseumawe City?

\section{Literature Review}

\subsection{Understanding Brand Image}

Brand image (brand image) is a representation of the overall perception of the brand and is formed from information and past experience of the brand (Tjiptono, 2005, p. 43). The image of the brand relates to attitudes in the form of beliefs and preferences for a brand. Consumers who have a positive image of a brand will be more likely to make a purchase. Brand image (brand image) can be considered a type of association that arises in the minds of consumers when remembering a particular brand. The association can simply appear in the form of a particular thought or image that is associated with a brand. This association can be conceptualized based on type, support, strength, and uniqueness (Simamora, 2007, p. 12).

Brand image refers to the memory scheme of a brand, which contains consumer interpretations of attributes, advantages, uses, situations, users and marketer characteristics and characteristics of the product or brand maker. Brand image is what consumers think and feel when they hear or see the name of a brand. Positive consumer images of a brand allow consumers to make purchases. A better brand is also the basis for building a positive corporate image. 
Understanding of images according to (Kotler, 2010, p. 129) that the image is a set of beliefs, ideas, and impressions, which are owned by someone against an object. According to (Simamora, 2007, p. 37), a strong brand requirement is the brand image. But (Simamora, 2007, p. 37) sharpens that brand image as a brand position, namely a clear brand image that is superior in superior terms relative to competitors. The image will eventually be good when the consumer has sufficient experience with the new reality. The new reality in question is that organizations actually work more effectively and have good performance.

\subsection{Understanding World of Mouth}

One of the form of promotion in marketing is word of mouth. Consumers are often directly involved in greeting and informing other potential consumers about their experiences in consuming a product or service. The process of communication between people is more through word of mouth communication. Because people talk to others every day, exchange ideas, exchange information, comment on each other and other communication processes. Actual consumer knowledge on a wide range of branded products more due to lack of communication by word of mouth (word of mouth communication). Word of mouth is basically a message about the product or service of a company, or about the company itself, in the form of comments about products, friendliness, honesty, the speed of service and other things that are felt and experienced by someone conveyed to others. The message conveyed to shape messages that are positive and negative $f$ depends on what is perceived by the message of the giver for services consumption. Based on the opinions of some experts above it can be concluded that word of mouth is a marketing activity that provides information on a product or service from one consumer to another to discuss, promote and want to sell a brand to others.

\subsection{Understanding Purchasing Interest}

Humans as buyers must use various considerations in buying or not buying a particular product. For example, the benefits of goods or services purchased the period of benefits, the satisfaction of which needs to be satisfied, whether that is primary, secondary or tertiary. Understanding of interest according to (Mowen and Minor, 2008) is a tendency and high enthusiasm or a great desire for something. Interest is one of the psychological aspects that have a considerable influence on behavior and interest is also a source of motivation that will direct someone to do what they do. Buying interest is formed by the influence of consumer attitudes towards a product and their belief in quality and price. In this case, marketers must understand consumer desires. Consumer buying interest, namely attitudes, interests, and actions taken by consumers in the decision making process and planning purchases of the number of brands. Consumer interest is strongly influenced by product characteristics, selection of the benefits of a product and prices determined by marketers.

\section{Methodology}

The location of the research that I will do is in Lhokseumawe City. The subjects of this study were consumers who bought Yamaha motorcycle products N-MAX in Lhokseumawe City. The population in this study were consumers who bought Yamaha motorbikes N-MAX 
in the city of Lhokseumawe, amounting to 170 consumers. From the results of the calculation of the Slovin formula, the number of samples for this study was 63 samples. Data collection technique that is questionnaire is a method of data collection conducted by giving questions to respondents with a questionnaire guide, and library study is a method of data collection carried out by reading books, literature, journals, references relating to this research and previous research related to the research being conducted. To see the effect, the authors used a multiple linear regression model to see how much influence the brand image $\left(\mathrm{X}_{1}\right)$ and word of mouth $\left(\mathrm{X}_{2}\right)$ against buying interest $(\mathrm{Y})$. linear regression multiple is a statistical model that is used to determine how much influence the independent variable has on the dependent variable or to make predictions about how changes in the value of the independent variable or increase or decrease. Following is the linear regression formula double as follows:

$$
\mathbf{Y}=\mathbf{a}+\mathbf{b}_{1} \mathbf{X}_{1}+\mathbf{b}_{2} \mathbf{X}_{2}+\varepsilon \mathbf{i}
$$

$$
\text { Description: }
$$

$\mathrm{Y}=$ Purchase Interest

a $=$ Constant

$\mathrm{b}=$ Regression coefficient

$\mathrm{X}_{1}=$ Brand Image

$\mathrm{X}_{2}=$ Word of Mouth

घi $=$ E error term

\subsection{Operational Definition of Variables}

1. Brand image $\left(\mathrm{X}_{1}\right)$ is $\mathrm{r}$ epresentasi of the overall perception of the brand and is formed of information and past experience to the brand.

2. Word of mouth $\left(\mathrm{X}_{2}\right)$ is $\mathrm{u}$ saha marketing triggers consumers to discuss, promote, recommend and sell the product/brand to other consumers.

3. Consumer buying interest $(\mathrm{Y})$ is $\mathrm{s}$ esuatu related to consumers plan to buy a certain product and how many units of the product is needed at a particular period.

\subsection{Validity test}

This validity test was conducted with the aim to determine the validity of the questionnaire or questionnaire. Validity here means a questionnaire or questionnaire used to measure what should be measured. The item validity test was done by SPSS by looking at the results of the correlation between each item with the total score on the corrected item-total correlation value greater or equal to the value of the $\mathrm{r}_{\text {table. }}$

\subsection{Reliability test}

Reliability test is a reliability test that aims to find out how far a measuring instrument is reliable or trusted. Reliability is related to the estimation of the extent of a measuring instrument when viewed from the stability or internal consistency of answers or questions if the observations are carried out repeatedly. 


\subsection{Hypothesis testing}

\subsubsection{T test (Partial Test)}

a. If the value of $t>t_{\text {table, }}$ then partially independent variables affect the dependent variable means of brand image $\left(\mathrm{X}_{1}\right)$ and word of mouth $\left(\mathrm{X}_{2}\right)$ partially has a significant effect on consumer buying interest $(\mathrm{Y})$.

b. If the value of $t_{\text {count }}<t_{\text {table }}$, then the independent variable partially does not affect the dependent variable, meaning brand image $\left(\mathrm{X}_{1}\right)$ and word of mouth $\left(\mathrm{X}_{2}\right)$ partially does not affect consumer buying interest $(\mathrm{Y})$.

\subsubsection{Test F (Test Simultaneously)}

a. If $\mathrm{F}_{\text {count }}>\mathrm{F}_{\text {table, }}$, then the independent variables simultaneously influence on dependent variable for example brand image $\left(\mathrm{X}_{1}\right)$ and word of mouth $\left(\mathrm{X}_{2}\right)$ simultaneously have a significant effect on consumer buying interest $(\mathrm{Y})$.

b. If $\mathrm{F}_{\text {count }}<\mathrm{F}_{\text {table }}$, then the independent variables simultaneously have no effect on dependent variable for example brand image $\left(\mathrm{X}_{1}\right)$ and word of mouth $\left(\mathrm{X}_{2}\right)$ simultaneously has no effect on consumer buying interest $(\mathrm{Y})$.

\section{Results And Discussion}

\subsection{Validity test}

Validity test serves to show the level of validity of an instrument. A valid instrument has high validity. The results of the validity analysis are shown by comparing the $r_{\text {count }}>r_{\text {table. The }}$. The following are the results of the validity test for this study in the following table:

Table 1. Results of Validity test

\begin{tabular}{|c|c|c|c|}
\hline No. & Variable & $\mathbf{r}_{\text {count }}$ & rtable \\
\hline \multirow[t]{5}{*}{1} & \multicolumn{2}{|c|}{ Brand Image $\left(\mathrm{X}_{1}\right)$} & \multirow[t]{5}{*}{0.2500} \\
\hline & $\mathrm{X}_{1.1}$ (Question 1) & 0.536 & \\
\hline & $\mathrm{X}_{1.2}$ (Question 2) & 0.601 & \\
\hline & $\mathrm{X}_{1.3}$ (Question 3) & 0.784 & \\
\hline & $\mathrm{X}_{1.4}$ (Question 4) & 0.634 & \\
\hline \multirow[t]{4}{*}{2} & \multicolumn{2}{|c|}{ Word of Mouth $\left(\mathrm{X}_{2}\right)$} & \multirow[t]{4}{*}{0.2500} \\
\hline & $\mathrm{X}_{2.1}$ (Question 1) & 0.753 & \\
\hline & $\mathrm{X}_{2.2}$ (Question 2) & 0.648 & \\
\hline & $\mathrm{X}_{2.3}$ (Question 3) & 0.717 & \\
\hline \multirow[t]{5}{*}{3} & \multicolumn{2}{|c|}{ Buying Interest ( Y ) } & \multirow[t]{5}{*}{0.2500} \\
\hline & $\mathrm{Y}_{1}$ (Question 1) & 0.533 & \\
\hline & $\mathrm{Y}_{2}$ (Question 2) & 0.695 & \\
\hline & $\mathrm{Y}_{3}$ (Question 3) & 0.684 & \\
\hline & $\mathrm{Y}_{4}$ (Question 4) & 0.744 & \\
\hline
\end{tabular}


Based on the results of the examinations obtained in the table, the $r_{\text {table }}$ value is obtained from (degree of freedom) $\mathrm{df}=(\mathrm{nk})$, where $\mathrm{n}$ is the number of research samples and the number of research variables, so the value $\mathrm{df}=(63-3)$ is obtained by 60 with a significant level of 0.05 , the $r$ table value obtained is 0.2500 . From these results it can be concluded that the overall variables of the question are said to be valid because they fulfill the assumptions, where the value of $r$ is calculated $>r_{\text {table }}$ value.

\subsection{Reliability test}

Reliability testing shows the extent to which an instrument can provide consistent measurement results if the measurement is repeated twice or more. The results of the variable reliability test analysis in this study can be seen in the table as follows:

Table 2. Results of Reliability test

\begin{tabular}{cccc}
\hline No. & \multicolumn{1}{c}{ Variable } & Value $(\boldsymbol{\alpha})$ & Information \\
\hline 1 & Brand Image $\left(\mathrm{X}_{1}\right)$ & 0.623 & R eliable \\
\hline 2 & Word of Mouth $\left(\mathrm{X}_{2}\right)$ & 0.696 & R eliable \\
\hline 3 & Buying Interest $(\mathrm{Y})$ & 0.791 & R eliable \\
\hline
\end{tabular}

From the table above it can be explained that the reliability test results in the table above shows that the alpha value of the independent variable brand image $\left(\mathrm{X}_{1}\right)$ is 0.623 , for the word of mouth variable $\left(\mathrm{X}_{2}\right)$ is 0.696 and for the dependent variable buying interest is 0.791 . So overall the items in each variable are reliable because they are greater than the value of 0.60 .

\subsection{Analysis Koefisien Multiple Linear Regression}

Multiple regression analysis is used to measure the effect of independent variables on the dependent variable. To find out whether brand image $\left(\mathrm{X}_{1}\right)$ and word of mouth $\left(\mathrm{X}_{2}\right)$ has a significant influence on buying interest $(\mathrm{Y})$, can be seen by comparing the significant value of $t_{\text {count }}$ in the following table:

Table 3. Results of Multiple Linear Regression Analysis

\begin{tabular}{cccccc}
\hline \multicolumn{5}{c}{ Coefficients $^{\text {a }}$} \\
\hline \multirow{2}{*}{ Model } & \multicolumn{6}{c}{ Unstandardized Coefficients Standardized Coefficients } & t & Sig. \\
\cline { 2 - 5 } & $\mathrm{B}$ & Std. Error & Beta & & \\
\hline 1 (Constant) & 1,408 & .559 & .418 & 2,521 & .14 \\
\hline Brand Image & .403 & .95 & .504 & .000 \\
\hline Word of Mouth & .514 & .112 & 4,578 & .000 \\
\hline
\end{tabular}

a. Dependent Variable: Interest buying

The results of multiple linear regression analysis can be seen as follows:

$$
Y=1,408+0,403 X_{1}+0,514 X_{2}+\varepsilon i
$$


From the results of these calculations, the constant has a value of 1.408 , which means that if the independent variable is brand image $\left(\mathrm{X}_{1}\right)$ and word of mouth $\left(\mathrm{X}_{2}\right)$ has a constant value, then buying interest $(\mathrm{Y})$ has a value of 1.408. The following are the results of calculations on the independent variables of this study, namely:

1. For the brand image coefficient value $\left(\mathrm{X}_{1}\right)$ has a value of 0.403 which means if the brand image $\left(\mathrm{X}_{1}\right)$ is increased by only one percent, then there will be an increase in buying interest (Y) of $0.403(40.3 \%)$.

2. For the word of mouth coefficient value $\left(\mathrm{X}_{2}\right)$ has a value of 0.514 which means if word of mouth $\left(\mathrm{X}_{2}\right)$ increased by one percent only, then there will be an increase in buying interest (Y) of $0.514(51.4 \%)$.

\subsection{Correlation Coefficient and Determination Coefficient Value}

To find out how much the correlation coefficient and the coefficient of determination between independent variables $(\mathrm{X})$ on the dependent variable $(\mathrm{Y})$ can be seen in the table of statistical test results. The following is a discussion of the results of data processing in the following table:

Table 4. Results of Correlation Coefficient of Determination

\begin{tabular}{|c|c|c|c|c|}
\hline \multicolumn{5}{|c|}{ Model Summary ${ }^{\text {b }}$} \\
\hline Model & $\mathrm{R}$ & R Square & Adjusted R Square & Std. Error of the Estimate \\
\hline 1 & $.525^{\mathrm{a}}$ & .276 & .252 & .44151 \\
\hline \multicolumn{5}{|c|}{ a. Predictors: (Constant), Word of Mouth, Brand Image } \\
\hline \multicolumn{5}{|c|}{ b. Dependent Variable: Interest buying } \\
\hline
\end{tabular}

From the results of this study it can be seen that the coefficient of $\mathrm{R}$ (correlation) is obtained at 0.525 , which means that the independent variable brand image $\left(\mathrm{X}_{1}\right)$ and word of mouth $\left(\mathrm{X}_{2}\right)$ has a relationship to the variable tied to buying interest $(\mathrm{Y})$ of 0.525 or $(52,5 \%)$. To see the magnitude of the influence of the independent variable (X) on the dependent variable (Y) can be seen in the results of the Adjusted $R^{2}$ test . From the test, the value of Adjusted $R^{2}$ is 0.252 which means that the influence of the brand image $\left(\mathrm{X}_{1}\right)$ and word of mouth $\left(\mathrm{X}_{2}\right)$ independent variables on the dependent variable of buying interest $(\mathrm{Y})$ is equal to 0.252 or $(25.2 \%)$. While the remaining 0.748 or $(74.8 \%)$ is influenced by other factors outside of this research model such as the marketing mix, promotion mix, consumer behavior and others.

\subsection{Hypothesis Testing}

\subsubsection{T test (Test Partial)}

a. Brand image variable $\left(\mathrm{X}_{1}\right)$ has a value of 2,074 $\mathrm{t}_{\text {count }}>\mathrm{t}$ table 2,001 . Where the brand image variable has a significant effect on buying interest. So it can be concluded that the brand 
image has a significant effect on consumer buying interest in Yamaha N-MAX motorcycles in Lhokseumawe City, with a significance level of 0,000 .

b. Word of mouth variable $\left(\mathrm{X}_{2}\right)$ has a value of $\mathrm{t}_{\text {count }} 4.578>\mathrm{t}_{\text {table }} 2.001$. Where that the word of mouth variable significantly influences buying interest. So it can be concluded that word of mouth has a significant effect on consumer buying interest in Yamaha N-MAX motorcycles in Lhokseumawe City, with a significance level of 0,000 .

\subsubsection{Test F ( Test Simultaneous)}

Based on the results of SPSS data processing, the calculated $\mathrm{F}$ value is obtained worth 11,427 . Then the value of $F_{\text {count }} 11.427>F_{\text {table }} 3.15$, where simultaneously or simultaneously the independent variables consisting of brand image $\left(\mathrm{X}_{1}\right)$ and word of mouth $\left(\mathrm{X}_{2}\right)$ significantly influence the purchase interest variable $(\mathrm{Y})$ with a significant level 0,000 . So it can be concluded that in this study the brand image $\left(\mathrm{X}_{1}\right)$ and word of mouth $\left(\mathrm{X}_{2}\right)$ variables influence consumer buying interest (Y) of Yamaha N-MAX motorbikes in Lhokseumawe City.

\section{Conclusions}

Based on the results of the study obtained the value of the correlation coefficient $(\mathrm{R})$ of 0.525 , where the correlation coefficient value there is a relationship between brand image $\left(\mathrm{X}_{1}\right)$ and word of mouth $\left(\mathrm{X}_{2}\right)$ on buying interest $(\mathrm{Y})$ that is equal to $52.5 \%$. For the determination coefficient (adjusted $R^{2}$ ) obtained at 0, 252, which means that the brand image $(\mathrm{X}-1)$ and word of mouth $\left(\mathrm{X}_{2}\right)$ affects the buying interest $(\mathrm{Y})$ amounted to $25.2 \%$ and the remaining $74.8 \%$ is influenced by other factors outside of this research model. For the partial test ( $\mathrm{t}$ test), it can be concluded that the brand image $\left(\mathrm{X}_{1}\right)$ and word of mouth $\left(\mathrm{X}_{2}\right)$ affect the buying interest of consumers (Y) motorcycle Yamaha N-MAX d i Lhokseumawe. For simultaneous testing, variable brand image $\left(\mathrm{X}_{1}\right)$ and word of mouth $\left(\mathrm{X}_{2}\right)$ simultaneously have an effect on the buying interest of consumers (Y) motorcycle Yamaha N-MAX at the Lhokseumawe.

\section{References}

[1] Kotler, P. (2010) Manajemen Pemasaran, Edisi 13 Jilid 1 \& 2. Edisi Terjemahan. Edited by B. Sabran. Jakarta: Erlangga.

[2] Mowen, J. and Minor, M. (2008) Consumer Behavior. Terjemahan. Edited by D. K. Yahya. Jakarta: Erlangga.

[3] Simamora, B. (2007) Strategies for Winning Profitability Markets. Jakarta: PT Index.

[4] Tjiptono, F. (2005) Brand Management and Strategy. Yogyakarta: Andi. 